\title{
Physiologic Specialization of Puccinia triticina on Wheat in the United States in 2014
}

\author{
J. A. Kolmer and M. E. Hughes, USDA-ARS Cereal Disease Laboratory, St. Paul MN 55108
}

\begin{abstract}
Kolmer, J. A., and Hughes, M. E. 2016. Physiologic specialization of Puccinia triticina on wheat in the United States in 2014. Plant Dis. 100:1768-1773.

Collections of Puccinia triticina obtained from wheat fields and breeding plots in the Great Plains, Ohio River Valley, and southeastern states, were tested for virulence in 2014 in order to determine the virulence of the wheat leaf rust pathogen population in the United States. Single uredinial isolates (380 total) were derived from the collections and tested for virulence phenotype on 20 lines of Thatcher wheat that are near-isogenic for leaf rust resistance genes. In 2014, 55 virulence phenotypes were described in the United States. Virulence phenotypes MBTNB, TBBGS, and TCRKG were the three most common phenotypes. Phenotypes MBTNB

and TCRKG are both virulent to $\operatorname{Lr11}$, and TCRKG is also virulent to Lr18 and Lr26. MBTNB and TCRKG were most common in the soft red winter wheat region of the southeastern states and the Ohio Valley. Phenotype TBBGS is virulent to $L r 39$, which is present in the hard red winter wheat cultivars, and $L r 21$, which is present in the hard red spring wheat cultivars. Isolates with virulence to $\operatorname{Lr} 11, \operatorname{Lr} 18$, and $\operatorname{Lr} 26$ were most common in the southeastern states and Ohio Valley region. Isolates with virulence to $\operatorname{Lr} 21$ and $L r 39$ were most common in the hard red wheat region of the southern and northern Great Plains.
\end{abstract}

Leaf rust, caused by Puccinia triticina Eriks., is a common disease of wheat (Triticum aestivum L.) in the United States and worldwide (Roelfs et al. 1992). The leaf rust fungus is well adapted to most continental and coastal climates where wheat matures in warm to hot conditions. Leaf rust is the most common rust on wheat in North America (Kolmer et al. 2009), South America (Germán et al. 2007), Central Asia (Morgounov et al. 2007), Russia (Morgounov et al. 2011), and central, eastern, and southern Europe (Hanzalová and Bartoš 2014) In the United States, leaf rust infections can overwinter in the southern Great Plains region of Texas, Oklahoma, and Kansas, and also in the southeastern region from Louisiana to Virginia (Roelfs 1989). As the winter wheat crop matures in the spring, urediniospores are produced on infected winter wheat plants and are carried by the southerly winds to the wheat producing regions in the Northern Great Plains, Ohio Valley, and northeastern states.

Since leaf rust is one of the most important diseases of wheat in the Great Plains, germplasm with leaf rust resistance is an important goal of wheat improvement programs in this region. The wheat cultivar Pawnee, released in 1942, and grown extensively in the southerncentral Great Plains until the early 1950s, had the leaf rust resistance gene $L r 3$, and was the first leaf rust resistant hard red winter wheat. However, within a few years, races or phenotypes of $P$. triticina with virulence to $L r 3$ increased, rendering the resistance in Pawnee ineffective. Other leaf rust resistant hard red winter wheat cultivars that had major selective effects on the $P$. triticina population have included: Agent with $L r 24$ released in 1968; Probrand 812 ( $L r 16$ 1985); Siouxland (Lr24, Lr26 - 1984); Jagger (Lr17, Lr37 - 1994); Jagalene (Lr24 - 2001); Overley (Lr39 - 2003), and Fuller (Lr17, Lr37, Lr39 - 2006) (J. A. Kolmer, unpublished data). These cultivars were all resistant to $P$. triticina when initially released; however,

Corresponding author: J. A. Kolmer; E-mail: jim.kolmer@ars.usda.gov

Accepted for publication 22 January 2016.

http://dx.doi.org/10.1094/PDIS-12-15-1461-SR

This article is in the public domain and not copyrightable. It may be freely reprinted with customary crediting of the source. The American Phytopathological Society, 2016. within a few years, phenotypes of $P$. triticina with virulence had increased to damaging levels. Hard red spring wheat cultivars with genes Lr2a, Lr10, Lr16, and Lr21 (Oelke and Kolmer 2004; Kolmer and Anderson 2011) and soft red winter wheat cultivars with $\mathrm{Lrl1}$, Lr26, and Lr18 (Kolmer 2003) have also selected virulence phenotypes of $P$. triticina. Long lasting resistance to $P$. triticina in wheat has been difficult to achieve due to the widespread overwintering of leaf rust on susceptible cultivars and the high variation for virulence to important leaf rust resistance genes.

The USDA-ARS Cereal Disease Laboratory has conducted virulence surveys of the wheat leaf rust fungus since 1978 (Long et al. 1985) to detect new virulence phenotypes and to monitor shifts of virulence phenotypes in the major wheat growing regions of the United States. Earlier surveys of leaf rust virulence that started in 1926 were conducted by the USDA-ARS in Kansas (Johnston et al. 1968) and Indiana (Mains and Jackson 1926). Similar surveys have been done in Canada since 1931 (Johnson 1956; McCallum and Seto-Goh 2006). In the United States (Leonard et al. 1992) and Canada (Kolmer 1999), data from leaf rust surveys have been used to characterize virulence dynamics and phenotypic diversity within and between wheat growing regions. The objectives of this study were to characterize the virulence of $P$. triticina populations in the United States in 2014 with the North American wheat leaf rust differentials and to compare these results with those of previous surveys (Kolmer and Hughes 2015).

\section{Materials and Methods}

Leaf rust occurrence and isolate collections. In 2014, USDAARS personnel and cooperators in the United States made a total of 187 uredinial collections of leaf rust from wheat plots and fields in surveys of the Great Plains, Ohio River Valley, and southeastern states. Field surveys of wheat were made by USDA-ARS personnel in southern Texas (late April and early May), southern Minnesota and southeastern South Dakota and Wisconsin (mid-June through early July), and northern Minnesota and North Dakota (late July through early August). Additional collections were made in wheat breeding nurseries, trap plots, and demonstration plots along the route. Nurseries typically contain a wide array of regional cultivars and breeding lines with various combinations of leaf rust resistance genes. Trap plots usually contain older, leaf rust susceptible wheat cultivars that are no longer prominent in commercial production. A 
collection consisted of one to several leaves with $P$. triticina uredinia from a single breeding line or cultivar. The leaves were air-dried at room temperature and stored at $4^{\circ} \mathrm{C}$ until spores were collected for inoculation and increase. Collections from inoculated nurseries were not included in the study.

Identification of virulence phenotypes. Urediniospores from each collection were used to inoculate 7-day-old seedlings of the wheat cultivar Little Club that had been treated with $30 \mathrm{ml}$ of a maleic hydrazide solution ( $1 \mathrm{~g}$ dissolved in 3 liters of $\mathrm{H}_{2} \mathrm{O}$ ) per pot to enhance spore production. Each pot of 10 to 20 seedlings was sprayed with $0.25 \mathrm{ml}$ of a suspension of spores in Soltrol 170 (Phillips Petroleum, Bartlesville, OK) mineral oil. After drying for $1 \mathrm{~h}$, inoculated plants were placed in a dew chamber with warm water in a heated lower tray and cooled sidewalls that allowed for the formation of free water on the seedling leaves. The inoculated plants were incubated in the dew chamber overnight at $18^{\circ} \mathrm{C}$. The plants were then placed in individual Plexiglas isolation chambers in a greenhouse where temperatures varied between 18 and $28^{\circ} \mathrm{C}$ daily with $16 \mathrm{~h}$ of supplemental greenhouse lighting. After 12 to 15 days, two to three seedlings were saved per collection, each with the primary leaf trimmed to isolate a single uredinium. When single uredinia began to form secondary rings, generally 9 to 14 days after inoculation, a small cyclone spore collector fitted to a vacuum line was used to collect urediniospores from single uredinia directly into 00 gelatin capsules that fit tightly to the cyclone spore collector. Urediniospores were collected separately from two to three single uredinia per collection. Urediniospores of the single-uredinial isolates were mixed with $0.25 \mathrm{ml}$ of oil in the 00 gel capsules and directly inoculated by atomization onto 7- to 8-day-old plants of the differential host series (five to seven plants per line) of near- isogenic lines of Thatcher wheat with single resistance genes $L r 1, L r 2 a, L r 2 c, L r 3, L r 3 k a, L r 9, L r 10$, Lr11, Lr14a, Lr16, Lr17, Lr18, Lr21, Lr24, Lr26, Lr28, Lr30, and $L r 39, L r 42$, and $L r B$. If an insufficient amount of urediniospores were obtained from the single uredinium to inoculate a differential set, the spores were increased on a pot of susceptible Little Club wheat seedlings prior to testing on the differential set.

Sets of differential lines were grown in the greenhouse and evaluated for rust infection type from April through June and from September through the end of January. Natural daylight was supplemented with high-pressure sodium lamps from 0800 to $2400 \mathrm{~h}$. After 10 to 12 days, infection types (IT) were recorded as either high (IT 3 to 4) or low (IT 0 to $2^{+}$) as previously described (Oelke and Kolmer 2004). A five letter code based on the original code proposed for P. triticina (Long and Kolmer 1989) describes the low or high infection types of each isolate to the 20 differential lines. Each letter corresponds to the infection types of four differentials. The Thatcher lines with genes $L r 1, L r 2 a, L r 2 c$, and $L r 3$ were the four lines in the first set of differentials; lines with genes $\operatorname{Lr} 9, \operatorname{Lr} 16, \operatorname{Lr} 24$, and $L r 26$ were the second set of differentials; lines with genes $L r 3 k a, L r 11, L r 17$, and $L r 30$ were the third set of differentials; lines with genes $\operatorname{LrB}$, $L r 10, L r 14 a$, and $\operatorname{Lrl} 18$ were the fourth set of differentials; and lines with genes $L r 21, L r 28, L r 39$, and $L r 42$ were the fifth set of differentials. Sets 1 to 3 are the same as described previously (Long and Kolmer 1989). The same first four sets of differentials have been used in P. triticina surveys in Canada (McCallum and Seto-Goh 2006). The fifth set of differentials was added for the first time in U.S. surveys in 2004, since $L r 21$ is present in spring wheat cultivars, $L r 39$ is present in winter wheat cultivars, and $L r 28$ differentiates $P$. triticina virulence phenotypes. Near-isogenic Thatcher lines with $L r 39$ and $L r 42$ were used for the first time in 2012. When possible, isolates with phenotypes that were recorded only once were tested a second time to confirm their phenotype.

Phenotype and virulence frequencies were determined for collections from eight agroecological geographic areas as shown and described in Figure 1. Collections were not obtained from areas 7 or 8 in 2014. A modified version of Nei's genetic distance (Nei 1972) between isolates in areas 1,2,3, 4, 5, and 6 was calculated with NTSYS-pc v2.1 (Exeter Software, Seatauket, NY) in which the frequency of isolates with virulence to a leaf rust resistance gene was used in place of allele frequency. The distance matrix of Nei's virulence distance between the areas was plotted with UPGMA clustering in NTSYS-pc v2.1.
The leaf rust resistance genes present in the current soft red winter wheat cultivars, hard red winter wheat cultivars, and hard red spring wheat cultivars were postulated based on infection types to different virulence phenotypes of $P$. triticina using previously cited methods (Kolmer 2003; Oelke and Kolmer 2004). The infection types of the cultivars to different $P$. triticina isolates and the postulated leaf rust resistance genotypes of the cultivars are available at the USDA-ARS Cereal Disease Laboratory website (http://www.ars.usda.gov/Main/ docs.htm?docid=16265) in the germplasm evaluation section.

\section{Results}

Leaf rust occurrence and isolate collections. Leaf rust was at low to moderate levels in south central Texas in early March, and by the middle of April was at high severity levels on flag leaves of susceptible cultivars. Extreme drought conditions in Oklahoma, Kansas, and Nebraska reduced wheat yields and also greatly reduced the incidence of leaf rust in these states. Very few collections of leaf rust were obtained from Kansas, Oklahoma, or Nebraska in 2014. The drought conditions in the southern-mid Great Plains region reduced the amount of leaf rust carried in the southerly winds to the spring wheat region of Minnesota, North Dakota, and South Dakota. Leaf rust was first observed in southern Minnesota in mid-June in winter wheat plots. By early August, leaf rust was present in spring wheat plots in central Minnesota at low levels. Leaf rust was present at low severity levels in eastern South Dakota in mid-July and in north central North Dakota in mid-July. By early August, leaf rust was present at moderate to high severity in central and eastern North Dakota. In the southeastern states and Mid-Atlantic states, leaf rust was more widespread but generally at low severity levels. Leaf rust was first observed in plots in southern Louisiana and Arkansas in mid-March. By mid-May, leaf rust was present in eastern North Carolina and Virginia. Due to persistent and widespread drought conditions throughout much of the wheat-growing regions in 2014, yield losses in wheat to leaf rust were negligible. A complete summary of the wheat leaf rust incidence and severity in 2014 in the United States can be found at the USDA-ARS Cereal Disease Laboratory website (http://www.ars.usda.gov/SP2UserFiles/ad_hoc/ 36400500Cerealrustbulletins/14CRB_final.pdf).

Samples of leaf rust were obtained from 15 states in areas 1, 2, 3, 4, 5, and 6 from a total of 187 collections.

Distribution of virulence phenotypes. In 2014, 55 virulence phenotypes of wheat leaf rust were identified in the United States from 380 single-uredinial isolates that were tested on the Thatcher lines (Table 1). Phenotypes MBTNB (19.5\%), TBBGS (11.6\%), and TCRKG $(11.3 \%)$ were the three most common phenotypes across the United States. No virulence phenotypes were found in all areas.

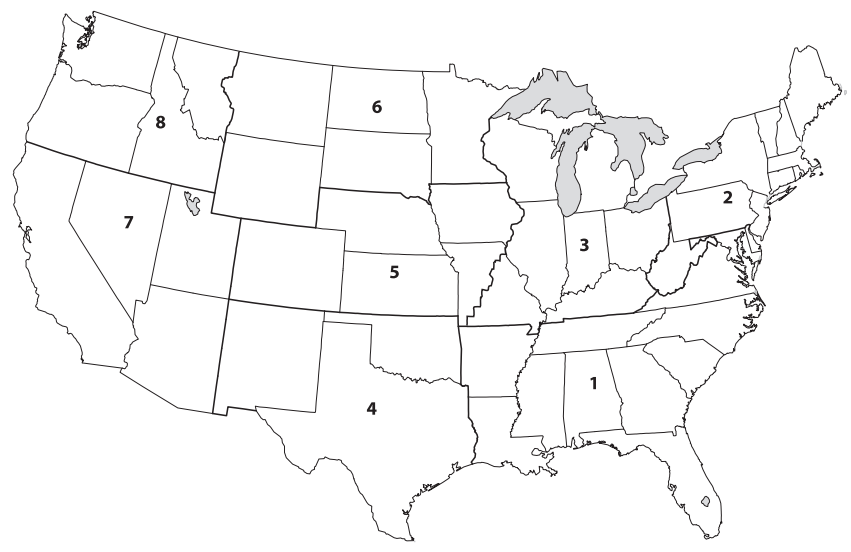

Fig. 1. Agroecological areas for Puccinia triticina in the United States. Area 1, mainly southern-adapted soft red winter wheat; Areas 2 and 3, mostly northern-adapted soft red and soft white winter wheat; Area 4 , mixed wheat types but primarily hard red winter; Area 5, hard red winter wheat; Area 6, mixed wheat types but primarily hard red spring and durum; Area 7, spring wheat planted in late fall; and Area 8, mixed wheat types but primarily soft white winter. 
Table 1. Number and frequency (\%) of virulence phenotypes of Puccinia triticina in the United States in 2014 identified by virulence to 20 a lines of wheat with single genes for leaf rust resistance

\begin{tabular}{|c|c|c|c|c|c|c|c|c|c|c|c|c|c|c|c|}
\hline \multirow[b]{2}{*}{ Phenotype } & \multirow[b]{2}{*}{ Virulence } & \multicolumn{2}{|c|}{ Area $1^{b}$} & \multicolumn{2}{|c|}{ Area $2^{\mathrm{c}}$} & \multicolumn{2}{|c|}{ Area $3^{\text {d }}$} & \multicolumn{2}{|c|}{ Area $4^{e}$} & \multicolumn{2}{|c|}{ Area $5^{\mathbf{f}}$} & \multicolumn{2}{|c|}{ Area $6^{\mathrm{g}}$} & \multicolumn{2}{|c|}{ Total } \\
\hline & & $\#$ & $\%$ & $\#$ & $\%$ & $\#$ & $\%$ & $\#$ & $\%$ & $\#$ & $\%$ & $\#$ & $\%$ & $\#$ & $\%$ \\
\hline MBDSB & $1,3,17, \mathrm{~B}, 10,14 \mathrm{a}$ & 0 & 0 & 0 & 0 & 0 & 0 & 1 & 1.2 & 0 & 0 & 0 & 0 & 1 & 0.3 \\
\hline MBDSD & $1,3,17, \mathrm{~B}, 10,14 \mathrm{a}, 39$ & 0 & 0 & 0 & 0 & 0 & 0 & 16 & 19.5 & 0 & 0 & 4 & 3.5 & 20 & 5.3 \\
\hline MBPNB & $1,3,3 \mathrm{ka}, 17,30, \mathrm{~B}, 14 \mathrm{a}$ & 0 & 0 & 0 & 0 & 1 & 3.1 & 0 & 0 & 0 & 0 & 0 & 0 & 1 & 0.3 \\
\hline MBPSB & $1,3,3 \mathrm{ka}, 17,30, \mathrm{~B}, 10,14 \mathrm{a}$ & 0 & 0 & 0 & 0 & 0 & 0 & 0 & 0 & 3 & 33.3 & 3 & 2.6 & 6 & 1.6 \\
\hline MBPSD & $1,3,3 \mathrm{ka}, 17,30, \mathrm{~B}, 10,14 \mathrm{a}, 39$ & 0 & 0 & 0 & 0 & 0 & 0 & 2 & 2.4 & 0 & 0 & 0 & 0 & 2 & 0.5 \\
\hline МВРТВ & $1,3,3 \mathrm{ka}, 17,30, \mathrm{~B}, 10,14 \mathrm{a}, 18$ & 0 & 0 & 0 & 0 & 0 & 0 & 0 & 0 & 1 & 11.1 & 0 & 0 & 1 & 0.3 \\
\hline MBTNB & $1,3,3 \mathrm{ka}, 11,17,30, \mathrm{~B}, 14 \mathrm{a}$ & 36 & 28.1 & 4 & 28.6 & 17 & 53.1 & 0 & 0 & 1 & 11.1 & 16 & 13.9 & 74 & 19.5 \\
\hline MCDSB & $1,3,26,17, \mathrm{~B}, 10,14 \mathrm{a}$ & 0 & 0 & 0 & 0 & 0 & 0 & 3 & 3.7 & 0 & 0 & 0 & 0 & 3 & 0.8 \\
\hline MCDSD & $1,3,26,17, \mathrm{~B}, 10,14 \mathrm{a}, 39$ & 0 & 0 & 0 & 0 & 0 & 0 & 8 & 9.8 & 0 & 0 & 0 & 0 & 8 & 2.1 \\
\hline MCPSB & $1,3,26,3 \mathrm{ka}, 17,30, \mathrm{~B}, 10,14 \mathrm{a}$ & 0 & 0 & 0 & 0 & 0 & 0 & 0 & 0 & 0 & 0 & 1 & 0.9 & 1 & 0.3 \\
\hline MCPSD & $1,3,26,3 \mathrm{ka}, 17,30, \mathrm{~B}, 10,14 \mathrm{a}, 39$ & 0 & 0 & 0 & 0 & 0 & 0 & 0 & 0 & 0 & 0 & 1 & 0.9 & 1 & 0.3 \\
\hline MCTNB & $1,3,26,3 \mathrm{ka}, 11,17,30, \mathrm{~B}, 14 \mathrm{a}$ & 11 & 8.6 & 4 & 28.6 & 6 & 18.8 & 0 & 0 & 0 & 0 & 2 & 1.7 & 23 & 6.1 \\
\hline MDDSB & $1,3,24,17, \mathrm{~B}, 10,14 \mathrm{a}$ & 0 & 0 & 0 & 0 & 0 & 0 & 0 & 0 & 0 & 0 & 1 & 0.9 & 1 & 0.3 \\
\hline MDTSB & $1,3,24,3 \mathrm{ka}, 11,17,30, \mathrm{~B}, 10,14 \mathrm{a}$ & 0 & 0 & 0 & 0 & 0 & 0 & 0 & 0 & 0 & 0 & 1 & 0.9 & 1 & 0.3 \\
\hline MFDSB & $1,3,24,26,17, \mathrm{~B}, 10,14 \mathrm{a}$ & 0 & 0 & 0 & 0 & 0 & 0 & 0 & 0 & 3 & 33.3 & 1 & 0.9 & 4 & 1.1 \\
\hline MFNQB & $1,3,24,26,3 \mathrm{ka}, 17, \mathrm{~B}, 10$ & 0 & 0 & 0 & 0 & 0 & 0 & 0 & 0 & 0 & 0 & 1 & 0.9 & 1 & 0.3 \\
\hline MFNSB & $1,3,24,26,3 \mathrm{ka}, 17, \mathrm{~B}, 10,14 \mathrm{a}$ & 0 & 0 & 0 & 0 & 0 & 0 & 2 & 2.4 & 0 & 0 & 1 & 0.9 & 3 & 0.8 \\
\hline MFPSB & $1,3,24,26,3 \mathrm{ka}, 17,30, \mathrm{~B}, 10,14 \mathrm{a}$ & 4 & 3.1 & 0 & 0 & 0 & 0 & 1 & 1.2 & 0 & 0 & 2 & 1.7 & 7 & 1.8 \\
\hline MFTSB & 1,3,24,26,3ka,11,17,30,B,10,14a & 0 & 0 & 0 & 0 & 0 & 0 & 0 & 0 & 0 & 0 & 1 & 0.9 & 1 & 0.3 \\
\hline MLDSD & $1,3,9,17, \mathrm{~B}, 10,14 \mathrm{a}, 39$ & 0 & 0 & 0 & 0 & 0 & 0 & 5 & 6.1 & 0 & 0 & 5 & 4.3 & 10 & 2.6 \\
\hline MLPSD & $1,3,9,3 \mathrm{ka}, 17,30, \mathrm{~B}, 10,14 \mathrm{a}, 39$ & 0 & 0 & 0 & 0 & 0 & 0 & 7 & 8.5 & 1 & 11.1 & 5 & 4.3 & 13 & 3.4 \\
\hline MMDSD & $1,3,9,26,17, \mathrm{~B}, 10,14 \mathrm{a}, 39$ & 0 & 0 & 0 & 0 & 0 & 0 & 1 & 1.2 & 0 & 0 & 1 & 0.9 & 2 & 0.5 \\
\hline MMPSD & $1,3,9,26,3 \mathrm{ka}, 17,30, \mathrm{~B}, 10,14 \mathrm{a}, 39$ & 2 & 1.6 & 0 & 0 & 0 & 0 & 7 & 8.5 & 0 & 0 & 0 & 0 & 9 & 2.4 \\
\hline PBDGJ & $1,2 \mathrm{c}, 3,17,10,28,39$ & 3 & 2.3 & 0 & 0 & 0 & 0 & 0 & 0 & 0 & 0 & 1 & 0.9 & 4 & 1.1 \\
\hline PBDQJ & $1,2 \mathrm{c}, 3,17, \mathrm{~B}, 10,28,39$ & 0 & 0 & 0 & 0 & 0 & 0 & 2 & 2.4 & 0 & 0 & 0 & 0 & 2 & 0.5 \\
\hline PBDSJ & $1,2 \mathrm{c}, 3,17, \mathrm{~B}, 10,14 \mathrm{a}, 28,39$ & 0 & 0 & 0 & 0 & 0 & 0 & 1 & 1.2 & 0 & 0 & 0 & 0 & 1 & 0.3 \\
\hline PLDDJ & $1,2 \mathrm{c}, 3,9,17,14 \mathrm{a}, 28,39$ & 0 & 0 & 0 & 0 & 0 & 0 & 1 & 1.2 & 0 & 0 & 0 & 0 & 1 & 0.3 \\
\hline PNDGJ & $1,2 \mathrm{c}, 3,9,24,17,10,28,39$ & 0 & 0 & 0 & 0 & 0 & 0 & 0 & 0 & 0 & 0 & 1 & 0.9 & 1 & 0.3 \\
\hline TBBGJ & $1,2 \mathrm{a}, 2 \mathrm{c}, 3,10,28,39$ & 0 & 0 & 0 & 0 & 0 & 0 & 6 & 7.3 & 0 & 0 & 0 & 0 & 6 & 1.6 \\
\hline TBBGS & $1,2 \mathrm{a}, 2 \mathrm{c}, 3,10,21,28,39$ & 1 & 0.8 & 0 & 0 & 0 & 0 & 1 & 1.2 & 0 & 0 & 42 & 36.5 & 44 & 11.6 \\
\hline ТВНТВ & $1,2 \mathrm{a}, 2 \mathrm{c}, 3,11,30, \mathrm{~B}, 10,14 \mathrm{a}, 18$ & 0 & 0 & 1 & 7.1 & 0 & 0 & 0 & 0 & 0 & 0 & 0 & 0 & 1 & 0.3 \\
\hline TBJGS & $1,2 \mathrm{a}, 2 \mathrm{c}, 3,11,17,10,21,28,39$ & 0 & 0 & 0 & 0 & 0 & 0 & 0 & 0 & 0 & 0 & 1 & 0.9 & 1 & 0.3 \\
\hline TBJSB & $1,2 \mathrm{a}, 2 \mathrm{c}, 3,11,17, \mathrm{~B}, 10,14 \mathrm{a}$ & 1 & 0.8 & 0 & 0 & 0 & 0 & 0 & 0 & 0 & 0 & 0 & 0 & 1 & 0.3 \\
\hline TBRJG & $1,2 \mathrm{a}, 2 \mathrm{c}, 3,3 \mathrm{ka}, 11,30,10,14 \mathrm{a}, 28$ & 1 & 0.8 & 0 & 0 & 0 & 0 & 0 & 0 & 0 & 0 & 0 & 0 & 1 & 0.3 \\
\hline TBRKG & $1,2 \mathrm{a}, 2 \mathrm{c}, 3,3 \mathrm{ka}, 11,30,10,14 \mathrm{a}, 18,28$ & 11 & 8.6 & 0 & 0 & 0 & 0 & 0 & 0 & 0 & 0 & 0 & 0 & 11 & 2.9 \\
\hline TBTNB & $1,2 \mathrm{a}, 2 \mathrm{c}, 3,3 \mathrm{ka}, 11,17,30, \mathrm{~B}, 14 \mathrm{a}$ & 3 & 2.3 & 0 & 0 & 0 & 0 & 0 & 0 & 0 & 0 & 0 & 0 & 3 & 0.8 \\
\hline TBTSB & $1,2 \mathrm{a}, 2 \mathrm{c}, 3,3 \mathrm{ka}, 11,17,30, \mathrm{~B}, 10,14 \mathrm{a}$ & 0 & 0 & 2 & 14.3 & 0 & 0 & 0 & 0 & 0 & 0 & 0 & 0 & 2 & 0.5 \\
\hline TCJSB & $1,2 \mathrm{a}, 2 \mathrm{c}, 3,26,11,17, \mathrm{~B}, 10,14 \mathrm{a}$ & 3 & 2.3 & 0 & 0 & 0 & 0 & 0 & 0 & 0 & 0 & 0 & 0 & 3 & 0.8 \\
\hline TCLJG & $1,2 \mathrm{a}, 2 \mathrm{c}, 3,26,3 \mathrm{ka}, 10,14 \mathrm{a}, 28$ & 0 & 0 & 0 & 0 & 0 & 0 & 1 & 1.2 & 0 & 0 & 0 & 0 & 1 & 0.3 \\
\hline TCRKG & $1,2 \mathrm{a}, 2 \mathrm{c}, 3,26,3 \mathrm{ka}, 11,30,10,14 \mathrm{a}, 18,28$ & 43 & 33.6 & 0 & 0 & 0 & 0 & 0 & 0 & 0 & 0 & 0 & 0 & 43 & 11.3 \\
\hline TCSQB & $1,2 \mathrm{a}, 2 \mathrm{c}, 3,26,3 \mathrm{ka}, 11,17, \mathrm{~B}, 10$ & 1 & 0.8 & 0 & 0 & 0 & 0 & 0 & 0 & 0 & 0 & 0 & 0 & 1 & 0.3 \\
\hline TCTNB & $1,2 \mathrm{a}, 2 \mathrm{c}, 3,26,3 \mathrm{ka}, 11,17,30, \mathrm{~B}, 14 \mathrm{a}$ & 1 & 0.8 & 0 & 0 & 0 & 0 & 0 & 0 & 0 & 0 & 0 & 0 & 1 & 0.3 \\
\hline TCTQB & $1,2 \mathrm{a}, 2 \mathrm{c}, 3,26,3 \mathrm{ka}, 11,17,30, \mathrm{~B}, 10$ & 1 & 0.8 & 0 & 0 & 0 & 0 & 0 & 0 & 0 & 0 & 0 & 0 & 1 & 0.3 \\
\hline TCTSB & $1,2 \mathrm{a}, 2 \mathrm{c}, 3,26,3 \mathrm{ka}, 11,17,30, \mathrm{~B}, 10,14 \mathrm{a}$ & 0 & 0 & 1 & 7.1 & 0 & 0 & 0 & 0 & 0 & 0 & 3 & 2.6 & 4 & 1.1 \\
\hline TDBGJ & $1,2 \mathrm{a}, 2 \mathrm{c}, 3,24,10,28,39$ & 0 & 0 & 0 & 0 & 0 & 0 & 0 & 0 & 0 & 0 & 1 & 0.9 & 1 & 0.3 \\
\hline TDBGQ & $1,2 \mathrm{a}, 2 \mathrm{c}, 3,24,10,21,28$ & 1 & 0.8 & 0 & 0 & 0 & 0 & 0 & 0 & 0 & 0 & 0 & 0 & 1 & 0.3 \\
\hline TDBJQ & $1,2 \mathrm{a}, 2 \mathrm{c}, 3,24,10,14 \mathrm{a}, 21,28$ & 0 & 0 & 0 & 0 & 0 & 0 & 0 & 0 & 0 & 0 & 1 & 0.9 & 1 & 0.3 \\
\hline TDCHG & $1,2 \mathrm{a}, 2 \mathrm{c}, 3,24,10,14 \mathrm{a}, 21,28$ & 1 & 0.8 & 0 & 0 & 0 & 0 & 0 & 0 & 0 & 0 & 0 & 0 & 1 & 0.3 \\
\hline TFTSB & $1,2 \mathrm{a}, 2 \mathrm{c}, 3,24,26,3 \mathrm{ka}, 11,17,30, \mathrm{~B}, 10,14 \mathrm{a}$ & 0 & 0 & 2 & 14.3 & 2 & 6.3 & 0 & 0 & 0 & 0 & 7 & 6.1 & 11 & 2.9 \\
\hline TLBGJ & $1,2 \mathrm{a}, 2 \mathrm{c}, 3,9,10,28,39$ & 0 & 0 & 0 & 0 & 0 & 0 & 1 & 1.2 & 0 & 0 & 0 & 0 & 1 & 0.3 \\
\hline TNBGJ & $1,2 \mathrm{a}, 2 \mathrm{c}, 3,9,24,10,28,39$ & 0 & 0 & 0 & 0 & 4 & 12.5 & 12 & 14.6 & 0 & 0 & 3 & 2.6 & 19 & 5.0 \\
\hline TNBJJ & $1,2 \mathrm{a}, 2 \mathrm{c}, 3,9,24,10,14 \mathrm{a}, 28,39$ & 0 & 0 & 0 & 0 & 0 & 0 & 3 & 3.7 & 0 & 0 & 8 & 7 & 11 & 2.9 \\
\hline TNRJJ & $1,2 \mathrm{a}, 2 \mathrm{c}, 3,9,24,3 \mathrm{ka}, 11,30,10,14 \mathrm{a}, 28,39$ & 4 & 3.1 & 0 & 0 & 0 & 0 & 0 & 0 & 0 & 0 & 0 & 0 & 4 & 1.1 \\
\hline TPBGJ & $1,2 \mathrm{a}, 2 \mathrm{c}, 3,9,24,26,10,28,39$ & 0 & 0 & 0 & 0 & 0 & 0 & 1 & 1.2 & 0 & 0 & 0 & 0 & 1 & 0.3 \\
\hline TPBJJ & $1,2 \mathrm{a}, 2 \mathrm{c}, 3,9,24,26,10,14 \mathrm{a}, 28,39$ & 0 & 0 & 0 & 0 & 2 & 6.3 & 0 & 0 & 0 & 0 & 1 & 0.9 & 3 & 0.8 \\
\hline Total & & 128 & & 14 & & 32 & & 82 & & 9 & & 115 & & 380 & \\
\hline
\end{tabular}

\footnotetext{
${ }^{a}$ Lines tested were Thatcher lines with genes $\operatorname{Lr} 1, \operatorname{Lr} 2 a, \operatorname{Lr} 2 c, \operatorname{Lr} 3, \operatorname{Lr} 9, \operatorname{Lr} 16, \operatorname{Lr} 24, \operatorname{Lr} 26, \operatorname{Lr} 3 k a, \operatorname{Lr} 11, \operatorname{Lr} 17, \operatorname{Lr} 30, \operatorname{Lr} B, \operatorname{Lr} 10, \operatorname{Lr} 14 a, \operatorname{Lr} 18, \operatorname{Lr} 21, \operatorname{Lr} 28, \operatorname{Lr} 39$ and $L r 42$.

b States of AR, GA, LA, NC, TN, and VA.

c State of NY.

d States of IL, IN, and WI.

e State of TX.

${ }^{\mathrm{f}}$ State of KS.

g States of MN, ND, and SD.
} 
In the southeastern states (area 1), 18 virulence phenotypes were found among the 128 isolates tested (Table 1). Phenotypes TCRKG (33.6\%), MBTNB (28.1\%), MCTNB (8.6\%), and TBRKG $(8.6 \%)$ were the four most common phenotypes in this area. In the northeastern states (area 2), six virulence phenotypes: MBTNB, MCTNB, TBHTB, TBTSB, TCTSB, and TFTSB were found among the 14 isolates that were tested. In the Ohio Valley states (area 3), six virulence phenotypes were found among the 32 isolates that were tested. Phenotypes MBTNB (53.1\%), MCTNB (18.8\%), and TNBGJ $(12.5 \%)$ were the three most common phenotypes in this area. In Texas and Oklahoma (area 4), 21 virulence phenotypes were found among the 82 isolates that were tested. Phenotypes MBDSD (19.5\%), TNBGJ (14.6\%), and MCDSD (9.8\%) were the three most common phenotypes in this area. In Kansas and Nebraska (area 5), five virulence phenotypes: MBPSB, MBPTB, MBTNB, MFDSB, and MLPSD, were found among the nine isolates that were tested. In South Dakota, North Dakota, and Minnesota (area 6), 27 phenotypes were found among the 115 isolates tested. Phenotypes TBBGS
(36.5\%), MBTNB (13.9\%), and TNBJJ (7.0\%) were the three most common phenotypes in this area.

Virulence frequencies. Frequencies of virulence to the $L r$ genes differed among the regional populations of $P$. triticina in the United States and are listed in Table 2. Virulence to $L r 16$ and $L r 42$ were not found in any areas. Virulence to $L r 1$ and $L r 3$ were at $100 \%$ in all areas. Virulence to $L r 21$ was found in areas 1,4 , and 6 . Virulence to $L r 39$ was highest in areas 4 and 6. Virulence to $L r 11$ was highest in areas 1,2, and 3 and was not found in area 4. Virulence to $L r 18$ was found in areas 1, 2, and 5. Virulence to the other $L r$ genes was found at variable levels across the different regions. Based on frequencies of virulence to $L r$ genes, the areas split into three groups using Nei's (Nei 1972) genetic distance adapted for virulence (Fig. 2). Isolates in areas 1,2 , and 3 were very closely related for virulence as were isolates in areas 4 and 6. Isolates in area 5 were somewhat separate from the other areas, most likely due to the low number of collections from that area in 2014. In past years, isolates from area 5 were closely related to isolates in areas 4 and 6. In area 1 (Fig. 3A), the frequency of

Table 2. Number and frequency (\%) of isolates of Puccinia triticina in the United States in 2014 virulent to 20 lines of wheat with single resistance genes for leaf rust resistance

\begin{tabular}{|c|c|c|c|c|c|c|c|c|c|c|c|c|c|c|}
\hline \multirow[b]{2}{*}{ Resistance gene } & \multicolumn{2}{|c|}{ Area $1^{\mathbf{a}}$} & \multicolumn{2}{|c|}{ Area $2^{b}$} & \multicolumn{2}{|c|}{ Area $3^{c}$} & \multicolumn{2}{|c|}{ Area $4^{d}$} & \multicolumn{2}{|c|}{ Area $5^{\mathrm{e}}$} & \multicolumn{2}{|c|}{ Area $6^{f}$} & \multicolumn{2}{|c|}{ Total } \\
\hline & $\#$ & $\%$ & $\#$ & $\%$ & $\#$ & $\%$ & $\#$ & $\%$ & $\#$ & $\%$ & $\#$ & $\%$ & $\#$ & $\%$ \\
\hline Lrl & 128 & 100.0 & 14 & 100.0 & 32 & 100.0 & 82 & 100.0 & 9 & 100.0 & 115 & 100.0 & 380 & 100.0 \\
\hline $\operatorname{Lr} 2 a$ & 72 & 56.3 & 6 & 42.9 & 8 & 25.0 & 25 & 30.5 & 0 & 0.0 & 67 & 58.3 & 178 & 46.8 \\
\hline $\operatorname{Lr} 2 c$ & 75 & 58.6 & 6 & 42.9 & 8 & 25.0 & 29 & 35.4 & 0 & 0.0 & 69 & 60.0 & 187 & 49.2 \\
\hline$L r 3$ & 128 & 100.0 & 14 & 100.0 & 32 & 100.0 & 82 & 100.0 & 9 & 100.0 & 115 & 100.0 & 380 & 100.0 \\
\hline $\operatorname{Lr} 9$ & 6 & 4.7 & 0 & 0.0 & 6 & 18.8 & 38 & 46.3 & 1 & 11.1 & 24 & 20.9 & 75 & 19.7 \\
\hline Lrl6 & 0 & 0.0 & 0 & 0.0 & 0 & 0.0 & 0 & 0.0 & 0 & 0.0 & 0 & 0.0 & 0 & 0.0 \\
\hline $\operatorname{Lr} 24$ & 10 & 7.8 & 2 & 14.3 & 8 & 25.0 & 19 & 23.2 & 3 & 33.3 & 30 & 26.1 & 72 & 18.9 \\
\hline $\operatorname{Lr} 26$ & 66 & 51.6 & 7 & 50.0 & 10 & 31.3 & 24 & 29.3 & 3 & 33.3 & 22 & 19.1 & 132 & 34.7 \\
\hline Lr3ka & 118 & 92.2 & 13 & 92.9 & 26 & 81.3 & 20 & 24.4 & 6 & 66.7 & 44 & 38.3 & 227 & 59.7 \\
\hline Lr11 & 116 & 90.6 & 14 & 100.0 & 25 & 78.1 & 0 & 0.0 & 1 & 11.1 & 31 & 27.0 & 187 & 49.2 \\
\hline $\operatorname{Lr} 17$ & 66 & 51.6 & 13 & 92.9 & 26 & 81.3 & 57 & 69.5 & 9 & 100.0 & 59 & 51.3 & 230 & 60.5 \\
\hline $\operatorname{Lr} 30$ & 118 & 92.2 & 14 & 100.0 & 26 & 81.3 & 17 & 20.7 & 6 & 66.7 & 42 & 36.5 & 223 & 58.7 \\
\hline $\operatorname{Lr} B$ & 63 & 49.2 & 14 & 100.0 & 26 & 81.3 & 56 & 68.3 & 9 & 100.0 & 56 & 48.7 & 224 & 58.9 \\
\hline Lr10 & 77 & 60.2 & 6 & 42.9 & 8 & 25.0 & 81 & 98.8 & 8 & 88.9 & 97 & 84.3 & 277 & 72.9 \\
\hline$L r 14 a$ & 120 & 93.8 & 14 & 100.0 & 28 & 87.5 & 59 & 72.0 & 9 & 100.0 & 65 & 56.5 & 295 & 77.6 \\
\hline $\operatorname{Lr} 18$ & 55 & 43.0 & 1 & 7.1 & 0 & 0.0 & 0 & 0.0 & 1 & 11.1 & 0 & 0.0 & 57 & 15.0 \\
\hline $\operatorname{Lr} 21$ & 2 & 1.6 & 0 & 0.0 & 0 & 0.0 & 1 & 1.2 & 0 & 0.0 & 44 & 38.3 & 47 & 12.4 \\
\hline $\operatorname{Lr} 28$ & 65 & 50.8 & 0 & 0.0 & 6 & 18.8 & 29 & 35.4 & 0 & 0.0 & 59 & 51.3 & 159 & 41.8 \\
\hline Lr39 & 10 & 7.8 & 0 & 0.0 & 6 & 18.8 & 74 & 90.2 & 1 & 11.1 & 74 & 64.3 & 165 & 43.4 \\
\hline $\operatorname{Lr} 42$ & 0 & 0.0 & 0 & 0.0 & 0 & 0.0 & 0 & 0.0 & 0 & 0.0 & 0 & 0.0 & 0 & 0.0 \\
\hline Total & 128 & & 14 & & 32 & & 82 & & 9 & & 115 & & 380 & \\
\hline
\end{tabular}

a States of AR, GA, LA, NC, TN, and VA.

b State of NY.

c States of IL, IN, and WI.

${ }^{\mathrm{d}}$ State of TX.

e State of KS.

${ }^{\mathrm{f}}$ States of MN, ND, and SD.

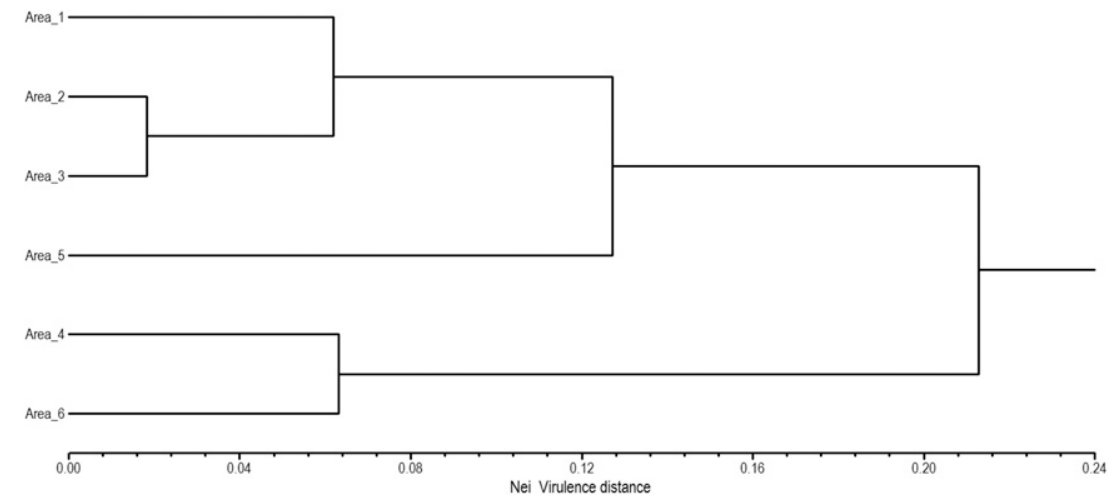

Fig. 2. UPGMA dendrogram of Nei's genetic distance adapted for virulence of Puccinia triticina isolates in areas 1, 2, 3, 4, 5, and 6 in the United States in 2014. 
isolates with virulence to $\operatorname{Lrl1}, \mathrm{Lrl8}$, and $\mathrm{Lr} 26$ increased slightly from 2013, while isolates with virulence to $\operatorname{Lr} 9$ decreased slightly. In area 4 (Fig. 3B), the frequency of isolates with virulence to Lr39 increased sharply, while isolates with virulence to $L r 24$ decreased from 2013. Isolates with virulence to $L r 17$ and $L r 26$ increased slightly. In area 6 (Fig. $3 \mathrm{C}$ ), isolates with virulence to $L r 21$ increased from 2013; isolates with virulence to $\operatorname{Lr} 2 a$ increased slightly, and isolates with virulence to Lr16 were not found.

\section{Discussion}

In 2014 as in previous years, the leaf rust resistance genes that are present in the hard red winter and soft red winter wheat cultivars have likely selected the most prevalent virulence phenotypes of $P$. triticina.
Phenotypes MBTNB and TCRKG, the most and third most common phenotypes, respectively, are virulent to gene $L r 11$, which is found in the soft red winter wheat cultivars that are grown in areas 1, 2, and 3 (Kolmer 2003). TCRKG is also virulent to $\operatorname{Lrl} 8$ and $L r 26$ that are present in the soft red winter wheat cultivars. The second most common phenotype, TBBGS, is virulent to $L r 21$ that is present in many of the hard red spring wheat cultivars such as Faller, Prosper, and Barlow (Kolmer and Anderson 2011) that are grown in Minnesota and North Dakota. The virulence of the P. triticina population in the United States did change somewhat in 2014 compared with the immediate previous years. In 2013, the three most common phenotypes were MBTNB, TNBGJ, and MCTNB (Kolmer and Hughes 2015).
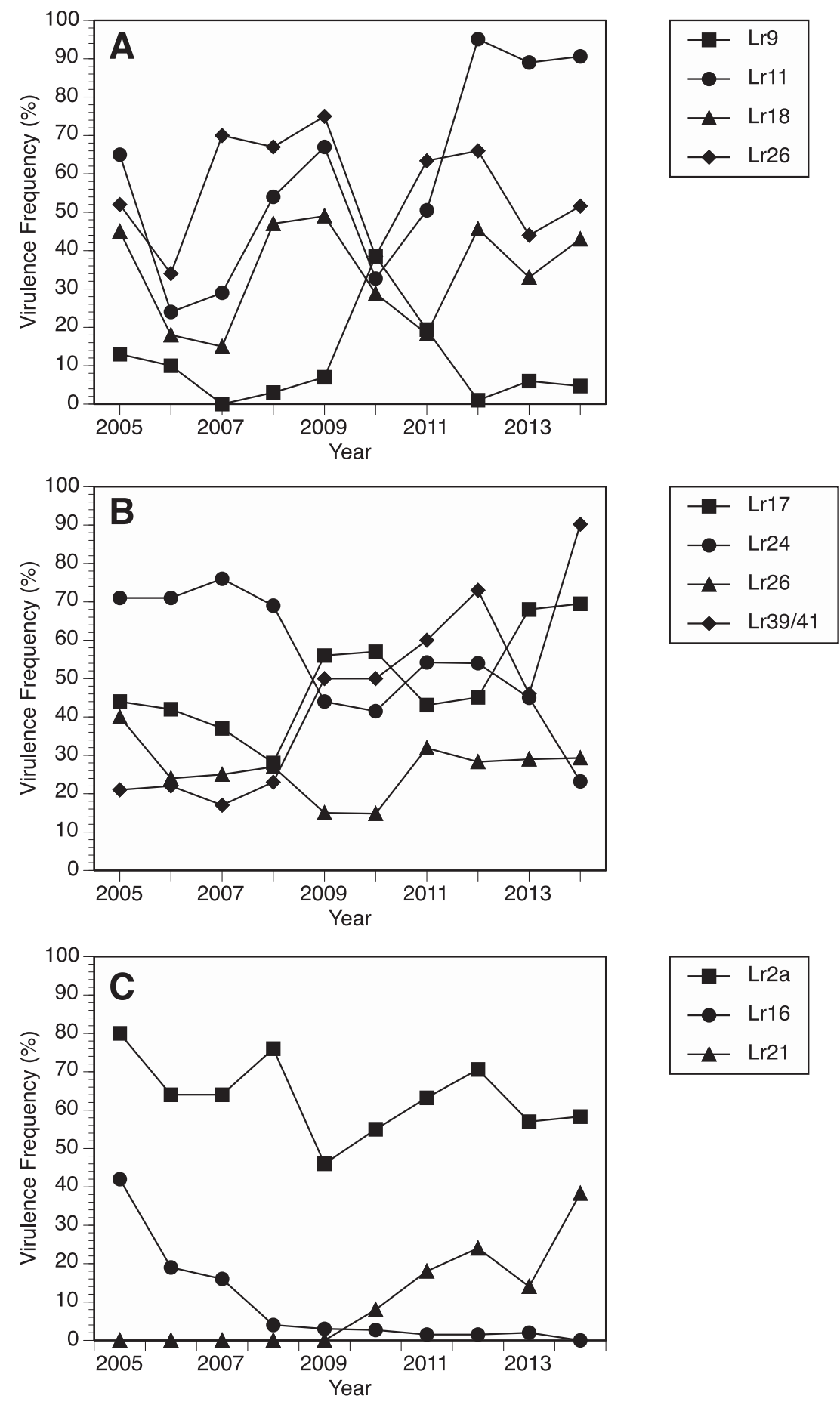

Fig. 3. Frequency (\%) of Puccinia triticina isolates with virulence to selected leaf rust resistance genes from 2005 to 2014 in the following areas of the United States: southeastern states (A, Area 1); southern Great Plains (B, Area 4); and northern Great Plains (C, Area 6). 
There were strong geographical differences in distribution of the $P$. triticina phenotypes. Phenotypes MBTNB (virulent to $L r 11$ ), TBRKG (virulent to $L r 11$ and $L r 18$ ), MCTNB (virulent to $L r 11$ and $L r 26$ ), and TCRKG (virulent to $L r 11, L r 18$, and $L r 26$ ) were the most common phenotypes in the areas 1 and 3 where soft red winter wheat cultivars with genes $L r 11, L r 18$, and $L r 26$ are grown. In the hard red wheat region of area 4, the common phenotypes MBDSD, MCDSD, TNBGJ, MLPSD, and MMPSD are virulent to Lr39 that is present in many cultivars in areas 4 and 5. Phenotypes MBDSD, MLPSD, and MMPSD are also virulent to $\operatorname{Lr} 17$, which was postulated to be present in the cultivars TAM 111 and Jagger. The geographic differences in phenotype distributions are also seen in Nei's virulence distance between isolates in the different areas. Isolates from the hard red wheat areas 4 and 6 of the Great Plains were highly similar for virulence and differed the most compared with isolates in areas 1,2, and 3 where soft red winter wheat cultivars are grown.

Some isolates with unusual virulence phenotypes were also found in 2014. Isolates with phenotypes of PBDGJ, PBDQJ, PBDSJ, PNDGJ, and PNDGJ were found in areas 1,4 , and 6 . These are unique compared with phenotypes with $\mathrm{M}$ - or $\mathrm{T}$ - phenotypes since they are avirulent to $L r 2 a$ and virulent to $L r 2 c$. These phenotypes are virulent to $\operatorname{Lr} 17$ and $\operatorname{Lr} 39$ that are present in many of the hard red winter wheat cultivars in the southern-mid Great Plains region.

In the absence of direct host selection, virulence to specific host resistance genes in populations of $P$. triticina is potentially influenced by a number of factors. Since $P$. triticina reproduces by the clonal production of urediniospores, virulence to different leaf rust resistance genes are often associated. Almost all isolates that are virulent to $\mathrm{Lrl7}$ are also virulent to $L r B$ and avirulent to $L r 28$. Similarly, all isolates that are virulent to $L r 21$ are also virulent to $L r 2 a$. These associations are maintained by the clonal asexual reproduction of the leaf rust pathogen. Virulence to leaf rust resistance genes can also be kept high by selection for an associated virulence. Isolates with virulence to $\operatorname{Lrl1}$, $L r 18$, and $L r 26$ that are present in the soft red winter wheat cultivars, are also virulent to $L r 3 k a$ and $L r 30$, even though it is unlikely that these genes have been directly selected for by resistant cultivars.

In past years, isolates with virulence to $\operatorname{Lr} 9$ were also virulent to Lr39. However, since 2011, virulence to these two genes is no longer highly associated as isolates that are virulent to $\operatorname{Lr} 39$ and avirulent to $\operatorname{Lr} 9$ are now common. The low frequency of virulence to $\operatorname{Lr} 9$ is likely because few current winter wheat cultivars have this gene, and also due to deleterious fitness effects that isolates with virulence to this gene may have in comparison with avirulent isolates. Virulence to Lr16 has declined steadily since 2005 . This is likely due to fewer hard red winter and spring wheat cultivars with this gene. Virulence to Lr42 is currently not found, likely due to the lack of released wheat cultivars with this gene, and possibly due to selection against virulence to this gene.

The hard red and soft red winter wheat cultivars that have various leaf rust resistance genes and are grown in different regions of the United States have selected for a population of $P$. triticina that is highly diverse for virulence. The continued cultivation of soft red winter wheat cultivars with $\operatorname{Lr} 11, \operatorname{Lr} 26$, and $\operatorname{Lr} 18$; hard red winter wheat cultivars with $\operatorname{Lr} 17, \operatorname{Lr} 24$, and $\operatorname{Lr} 39$; and spring wheat cultivars with $\operatorname{Lr} 21$, has selected a $P$. triticina population in the United States that is highly diverse and responds rapidly to the use of new effective leaf rust resistance genes in wheat germplasm. As new leaf rust resistant cultivars are released, it will be important to continue to determine the virulence of $P$. triticina collections in order to determine if these cultivars have selected virulent phenotypes of leaf rust.

\section{Literature Cited}

Germán, S. E., Barcellos, A., Chaves, M., Kohli, M., Campos, P., and de Viedma, L. 2007. The situation of common wheat rusts in the Southern Cone of America and perspectives for contol. Aust. J. Agric. Res. 58: 620-630.

Hanzalová, A., and Bartoš, P. 2014. Virulence surveys of wheat leaf rust in the Czech Republic and resistance genes in registered cultivars. Czech J. Genet. Breed. 50:241-246.

Johnson, T. 1956. Physiologic races of leaf rust of wheat in Canada 1931 to 1955 Can. J. Agric. Sci. 36:323-332.

Johnston, C. O., Caldwell, R. M., Compton, L. E., and Browder, L. E. 1968 Physiologic Races of Puccinia recondita f. sp. tritici in the United States from 1926 through 1960. USDA Technical Bulletin 1393:1-18.

Kolmer, J., Chen, X., and Jin, Y. 2009. Diseases which challenge global wheat production - the wheat rusts. Pages 89-124 in: Wheat Science and Trade. B. Carver, ed. Wiley Blackwell, Ames, IA.

Kolmer, J. A. 1999. Virulence dynamics, phenotypic diversity, and virulence complexity in two populations of Puccinia triticina in Canada from 19871997. Can. J. Bot. 77:333-338.

Kolmer, J. A. 2003. Postulation of leaf rust resistance genes in selected soft red winter wheats. Crop Sci. 43:1266-1274.

Kolmer, J. A., and Anderson, J. A. 2011. First detection in North America of virulence in wheat leaf rust (Puccinia triticina) to seedling plants of wheat with $L r 21$. Plant Dis. 95:1032.

Kolmer, J. A., and Hughes, M. E. 2015. Physiologic specialization of Puccinia triticina on wheat in the United States in 2013. Plant Dis. 99:1261-1267.

Leonard, K. J., Roelfs, A. P., and Long, D. L. 1992. Diversity of virulence within and among populations of Puccinia recondita f. sp. tritici in different areas of the United States. Plant Dis. 76:500-504.

Long, D. L., and Kolmer, J. A. 1989. A North American system of nomenclature for Puccinia recondita f.sp. tritici. Phytopathology 79:525-529.

Long, D. L., Schafer, J. F., and Roelfs, A. P. 1985. Specific virulence of Puccinia recondita f. sp. tritici in the United States from 1978 through 1983. Plant Dis. 69:343-347.

Mains, E. B., and Jackson, H. S. 1926. Physiologic specialization in the leaf rust of wheat, Puccinia triticina. Phyopthology 16:89-120.

McCallum, B. D., and Seto-Goh, P. 2006. Physiological specialization of Puccinia triticina, the causal agent of wheat leaf rust, in Canada in 2004. Can. J. Plant Pathol. 28:566-576.

Morgounov, A., Ablova, L., Babayants, O., Babayants, L., Bespalova, L., Khudormov, Z., Litvinenko, N., Shamanin, V., and Syukov, V. 2011. Genetic protection of wheat rusts and development of resistant varieties in Russia and Ukraine. Euphytica 179:297-311.

Morgounov, A., Rosseeva, L., and Koyshibayev, M. 2007. Leaf rust of spring wheat in Northern Kazakhstan and Siberia: incidence, virulence, and breeding for resistance. Aust. J. Agric. Res. 58:847-853.

Nei, M. 1972. Genetic distance between populations. Am. Nat. 106:283-292.

Oelke, L. M., and Kolmer, J. A. 2004. Characterization of leaf rust resistance in hard red spring wheat cultivars. Plant Dis. 88:1127-1133.

Roelfs, A. P. 1989. Epidemiology of the cereal rusts in North America. Can. J. Plant Pathol. 11:86-90.

Roelfs, A. P., Singh, R. P., and Saari, E. E. 1992. Rust Diseases of Wheat: Concepts and methods of disease management. CIMMYT, D. F., Mexico. 